\title{
Culture Mutation in the Era of Globalization: Africa in Perspective
}

\author{
Luke A Amadi, Imoh Imoh-Ita, Edmund F Obomanu \\ Department of Political Science \& Administrative Studies \\ University of Port Harcourt, Nigeria
}

\begin{abstract}
This article explored fundamental changes taking place in the periphery African societies within a cultural context in the era of resurgent Western globalization to determine whether such changes are in line with culture preservation or otherwise. It conceptualized these changes in the milieu of culture mutation and examined how this has resulted to new identity at variance with existing cultural values and how in turn it undermined culture sustainability and transcendence. To advance a cohesive argument, it deployed secondary and primary data sources for a broader illumination of propositional and oppositional debates and underlying assumptions of globalization in cultural contexts. It proposed a critical policy re-evaluation of the content of Western globalization and foregrounded the inevitability of long term culture dislodgement and possible extinction. The article suggested the confrontation of globalization through culture reinstitution, value reorientation and strategic incorporation of periphery cultures into the globalization project.
\end{abstract}

Keywords: Globalization, culture mutation, identity, culture sustainability, development, Africa

\section{INTRODUCTION: GLOBALIZATION AND RECONFIGURATION OF CULTURAL IDENTITY}

The study of globalization in cultural anthropology has become increasingly necessary in exploring "new societies" and "new identity". Dorin,(2006:3)recounts that although Paul Valeri noted the emergence of the "finite world" as early as 1931, that globalization in culture contexts is recent. She contends that what is called globalization theories in cultural anthropology and cultural sociology has very rarely been systematically studied irrespective of a vortex of writings on the subject of globalization.

A new society termed "the network society" is emerging composed of networks such as electronic networks including the internet and similar computer networks. Manuel Castells argues that the electronic hypertext has equally emerged with interface on globalization and information system (Castells, 2000:693). Such emerging new societies have implications for peoples' identity. Huntington (1996), shows that post- Cold War era was marked with changes in peoples' identities and what those identities symbolize. He identified the reconfiguration of global politics along cultural lines.

This ongoing "reconfiguration" which includes changes in lifestyle, symbols, language, communication, songs, stories, modes of behavior, including food, dressing, sexuality, etc, has swept across Africa via the Western globalization networks. Globalization has been widely discussed in development circles since at least the 1980s, indeed, the debate has moved on. Although it gained recent visibility in culture studies, since the 1960s, the Marxists criticize the spread of mass culture propagated by Western cultural industries in the rest of the world (Dorin, 2006).

The intense controversy surrounding globalization is evident in the no less heated debate over cultural identity in postcolonial theory. Globalization has increasingly become a commonly employed but complex and contradictory term (Rosenau, 1996). It has equally become a critical concept in virtually every sphere of life including culture, politics, sociology, economics, history, identity etc. This presupposes the existence of different perspectives on globalization. Some conceive globalization as instrument of democratization and liberalism (Tomlinson, 1999), others have attacked it as a neocolonial discourse encapsulated in Western capitalism and exploitation such as cultural imperialism (Sarmela, 1975; Appadurai, 1996; Amadi and Agena, 2015).

Cultural globalization reinforces recent interest on interrogation of Western globalization. According to Hofstede (1980) culture is a "collective programming of the mind which distinguishes the members of one category (i.e. National, regional, gender, age, social class, profession) of people from another". Cultural imperialism becomes easily associated with globalization as it underscores systemic 
dislodgement and subtle imposition of Western culture on the periphery. According to Sarmela (1975), "cultural imperialism is the economic, technological and cultural hegemony of the industrialized nations, which determines the direction of both economic and social progress, defines cultural values, and standardizes the civilization and cultural environment throughout the world".

Culture mutation easily becomes the resultant effect of cultural imperialism. It is a process of culture contact and dislodgement in which the dominant culture is subtly or obviously imposed on the recessive culture (Amadi and Agena, 2015). Within Africa, it is important to explore the resurgent intellectual curiosity on the trajectories of globalization and culture mutation. And ideal to make a process statement of how this happens as opposed to making arguments about globalization and cultural change or identities without explicit reference to globalization and culture mutation nexus especially in postcolonial and the new technology era. Rodney, (1972) argues that Africa had contacts with the rest of the world around the 15th century largely through trade, encompassing trans-Atlantic slave trade. Culture mutation is a colonial legacy which postcolonial African societies inherited from Western culture contacts within the colonial institutional frameworks. As the emergent African elite became purveyors of Western lifestyles including dress codes(tie and shirts, suits, trousers, shoes etc), living in Government Reserved Areas(GRAs),imbibing Western consumption patterns such as drinking of Western made gin, coffee, tea, cigarettes, burger, use of bicycles (mainly by colonial District Officers-DOs), automobiles by the emergent post - colonial senior civil servants etc, these new cultural identities superimposed by the West subtly calcified overtime.

Peter Eke identified Africa in the dilemma of two publics, one in the rural setting, the other in the colonial urban setting (Ekeh, 1975). This has extended to the neoliberal era with resurgent globalization. Such linkages are important to understand the cultural impasse confronting the 21st century Africa in the era of Western globalization. Cultural globalization is therefore a general process of homogenization which in turn results culture dislodgement (Dorin, 2006). However, sustained treatments that theorize globalization and culture mutation is scant. To some extent, this marginalization mirrors the concern of cultural studies in the periphery societies directly engaging postcolonial, post-modernity and post-developmental debates (Appadurai, 1996; Ferguson, 2006; Miege,2011;Pieterse,2012; Amadi,2012). This dynamic reinforces the need for an important theorizing of globalization in culture context.

This article focuses on globalization and culture mutation. It builds on cultural imperialism thesis and argues that in post modernity, a rebranded model of modernization remerged namely; globalization, to foster Western capitalist interests. This serves as an opportunity to provide a novel critical theoretical exploration of post- colonial developmentalism, more so, an engagement to reevaluate periphery cultures and globalization in the neoliberal era. Despite empirical limitations which pose some challenges and largely accounts for the superficial and uncritical engagement in research on periphery cultures, the article argues that globalization and culture mutation nexus remains theoretically vague and empirically arduous which compels a distinctive research to test the variables and address these concerns with regards to globalization. This limitation not-withstanding, the policy and research utility of this study is discernible as it aims to provide extant understanding of the critical relevance of culture sustainability.

The article demonstrates that globalization and its understanding needs to be re-examined in culture contexts for the ways in which its practice and uses affect culture among the poor societies. The article takes the primary task of critical re-thinking of current globalization as defining paraphernalia of culture mutation. Aware that culture mutation arising from globalization may not always have a negative effect, the main argument is culture preservation as the article contends that the contradictions of asymmetrical capitalist system are more centrally linked to exploitation of the periphery cultures believed to be vulnerable and prone to dislodgement. Moreover, that culture mutation is inextricably bound with disarticulation of the idyllic socio- cultural norms and ethics of Africa within the capitalist order requires urgent policy attention. The objective is to confront globalization and refute existing ideas and knowledge which posits that globalization should be wholly accepted. Alternatively, the article argues that key components of African society is eroded by globalization antics namely; African cultural heritage and identity. The article suggests possible ways this could be preserved.

The rest of the article is structured as follows; the theoretical framework and methodology, a review of the literature, dimensions of culture mutation and conclusion. 


\section{TheORETICAL FrameWORK AND METHODOLOGY}

Primary data on culture mutation in Africa was collected through self -administered primary survey conducted between May 2011 and January 2013. The survey was based on Amadi and Agena (2015) earlier survey on culture mutation among the Igbo of Eastern Nigeria. Semi -Structured questionnaires were administered to respondents on globalization and culture mutation in Africa. A simple random sampling technique was used to collect primary data based on sample size of 1,500 respondents in the twenty randomly selected African countries. The instrument of primary data collection was a semistructured questionnaire titled; Globalization and Culture Mutation in Africa (GLOCULMA) with reliability index of 0.88 . Percentages, weighted mean and standard deviation were used to answer the research questions.

Virtual focused group discussions(VFGDs) were conducted online with targeted audience drawn from the academia, media, policy makers, social workers and culture experts, the discussion which took about six months (March-August, 2015), was periodically conducted. Extensive review of relevant secondary data that span the period 1975 to 2014 was also conducted to explore the dynamics of globalization induced culture mutation.

Secondary data sources that particularly builds on the cultural imperialism framework was deployed to provide a deepened and broadened globalization/culture mutation debate (Sarmela, 1975; Said, 1993; Kraidy, 2002; Miege, 2011;Amadi and Agena, 2015). The study follows Sarmela (1975:13) who underscored the logic of cultural imperialism theoretical framework encompassing socioeconomic, cultural and technological hegemony of the industrialized societies, that increasingly tele guides the focus of both economic and social progress, directs and propagates "Western ideologies, sexual symbols and ideals of beauty, western working methods and leisure activities, western foods, western pop idols and the western concept of human existence have become objectives, examples and norms everywhere in the world. But there are too many dispossessed people who have amassed a few western material possessions, but no longer have any birthplace, home or final resting-place".

The article makes a novel theoretical contribution which seeks to demonstrate how globalization has given rise to the mutation of African culture. To demonstrate evidence of culture mutation, the paper explores Africa in culture contexts to demonstrate the rich cultural heritage and the possible nexus with globalization and specific mutated African cultural values such as African oral tradition, folklores, consumption patterns, dress code, lifestyles etc. This would be integrated into the wider globalization and culture mutation debate. What follows is Africa in culture contexts.

\section{Africa in Culture Contexts}

The understanding of African cultural values is important in order to illuminate the dynamics of culture mutation. Africa is a mosaic of cultures, ethnic and linguistic groups. It has an estimated land mass of 11,699 square miles with an estimated population of 642 million, accounting for $12 \%$ of the world's population (Kwame, 2006).

The continent is linguistically and ethnically diverse with over fifty nations (Ajayi, 2006). It has abundant human and natural resources, including minerals, timber and highly productive vegetation, however, it is the poorest region in the world (Collier, 2007; Amadi, 2012). Edward Said (1994) provides meanings of culture which include divergent practices such as arts, communication, and representation with limited autonomy from the economic, social, and political domains. He shows that these human expressions encompass an aesthetic dimension reflective of art which gives rise to entertainment and pleasure. The next as he argued involves commodity which explains what defines a people. He contends that through culture society is seen in the context of its strength and weaknesses Sarmela (1975) identifies super culture and local culture and contends that global culture has significant influence on the local culture.

Culture is classified as material and non- material. Material culture includes those cultural embodiments we see and touch, they are tangible such as food, dresses, etc. While non material culture involves those cultural embodiments that we neither see nor touch. They are intangible and include beliefs, values, norms, myths, etc. In idyllic terms, Africa has powerful cultural heritage including traditional kingdoms and cultural relics encompassing traditional dances, folklores, costumes, sculpture, pottery, body painting, jewelry made from cowry shell berries, metal work, sculptures, feathers, masks, deities, ancestors, spirits, myths, artefacts such as early neolithic rock 
carvings, wood carvings, brass, crafts, leather art works, languages, religions, cuisine, dressing , hunting, the Egyptian great wonders etc. Depictions of African local material culture, such as food, dressing, music and dance are parts of African community life, with instruments such as drums, sambas, lute, flute and trumpet.

Most songs depict rich cultural values, philosophy and African identity. African dancers dress uniquely, adorned elegantly with masks, head gears, body paintings with native white chalk etc during dances such as Ekpe and Ojionu among the Owerri Igbo. Others are the mmanwu (masquerade) dance in Eastern Nigeria (Amadi and Agena, 2015). There are similar mask dances among the Efik,Oron,Akwibom etc in South -South Nigeria. Others are the boat regatta among the riverine areas in the Niger Delta Nigeria. The folklore is didactic as they are rooted in African morality, myth and ancestry (Amadi and Agena 2015). Africa is rich in clothing and fabrics from the Akwete cloth weavers in Ndoki Eastern Nigeria, (Amadi and Agena, 2015). Hijab worn by Tunisian women, Shemma fabrics for Ethiopian women, the netala (Shawls), gele (long head gear) in Western Nigeria, Etibor adorned by the Ijaws of South-South Nigeria, the Agbada of the Muslim Hausa/Fulani in Northern Nigeria and Yoruba in Southwest Nigeria, the Ashanti Kente and Ankara clothes in Ghana, (Amadi and Agena, 2015), the Zulus of South Africa are known for a variety of attires made of animal hides symbolic of their rich culture. The Igbo are adorn with akwa (Cloths from wrapper fabrics) (Amadi and Agena, 2015).

Africa has powerful deities which are integral part of their world view,Ogun among the Yoruba, Amadioha among the Igbo. Archaeological evidence suggests that aboriginal tribes inhabited the Nile basin decades preceding the imperial history of the Pharaoh. Such evidence shows that Africa has well developed and systemic agricultural practices which started around 6000 B.C. Including skilled works such as iron, carvings, weaving largely refined by the Nok culture and the terracotta(Wikipedia, 2015).Africa also had great trade centers and routes such as the Kanem Bornu, Mali, Fulani, Dahomey, Oyo, Ashanti and Songhay empires in West Africa.

Non material culture, such as African religion, mores and spirituality represent dimensions of cultural philosophy and values including belief system etc. In this paper, we argue that the culture of a people is peculiar and distinct about them including their mannerisms and existential realities overtime. It is the totality of the ways of life of a people. This is suitable for our understanding of culture mutation which is at variance with culture preservation and sustainability. A review of the literature follows.

\section{REVIEW OF THE LITERATURE}

The literature and debates on globalization and culture mutation invite analytical re-engagement following the Western cultural domination and imperialism (Kraidy, 2002). Globalization means different things to different people. It re-emerged as a redirection of the resurgent vortex of global social changes and interactions in contemporary development studies from both oppositional and propositional perspectives. In recent times, it has been increasingly opposed as reflective of Western values (Appadurai, 1996;Gidens,1999; Kraidy,2002;Stiglitz,2005). Globalization examines the complex socio-cultural, political, economic, technological and psychological relations between human and non- human entities. A number of literatures are discussing aspects of globalization. The International Monetary Fund (2000) defined globalization in the context of "increasing integration of economies around the world", necessitated by trade and financial flows.

Again, the impact of dependency theories of globalization on the existence of society where development in the West translates to poverty in the periphery is discernible (Frank,1968;Dos Santos,1970). Amin, (1997) reinforces the dialectics of capitalist exploitation in the Age of globalization and provides theoretical evidence of growing economic asymmetry in the global North and South. There are debates among scholars that globalization encompasses socio- political interactions and relationships that underscores the modern world System (Appadurai, 1996; Giddens, 1999; Rosemond,1999). Accordingly, Rosemond (1999) contends that there are debates in the academia as to whether globalization is taking place or has already occurred, that such debates try to understand the nexus between propositional and oppositional perspectives to globalization as wells as its historical significance. Proponents such as Meyer and Hannan (1979) applaud some level of uniculturality which according to them bind societies and the world together. Similarly, the hyper 
globalists reinforce the borderless world debate. Ohmae, (1995) explores the practicalities of such borderless society indicating its liberalization interface.

Such neo liberal debates are echoed in most Western scholarship. Globalization puts identity in question. Hall, et al., (1999) provide a critical perspective and observe that the notion of "identity" has been contentious in social theory. Stressing the decline of old identities resulting to new identities which seem to divide the modern world giving rise to a crisis of identity, this as they contend, dislocates the modern societies. Central to this contention is that cultural factors will be major civilizations reshaping the future. This is what Huntington (1997) refers to as a civilization identity often deployed to mask the glaring pursuit of material wealth or power by the high income countries of the global North. Padersen (2008) tends to be dismissive of any notion of clash of civilizations despite resurgent culture changes across the globe and argues that different ways of life inevitably compete and some-times clash. That one can hold this view without advocating a clash of civilizations in the sense of a battle between religions.

Fukuyama (1989) recounts that such materialism discountenances the increasing attachment to ideology and culture rather contends that man is largely a rational, profit maximizing being. This increasingly informs the globalization prevarication which has been interpreted in numerous and even contradictory ways by several scholars. Ritzer (2003) and Amadi (2012) observe that trends in the multilateral organizations and Bretton Woods institution suggest that the developed nations are not in a hurry to facilitate the development of the developing ones. Carnoy (2000) argues on the sustainability of the information age, identifying its various facets in the family and the workplace.

The multidimensional strands of globalization is amply reinforced (Giddens,1999).Such perspective informs the central strand of our debate, though the paper focuses on cultural globalization. This view is consistent with debates which demonstrate the existence of global inequality as globalization ensues (Hirst and Thompson, 1997;Appadurai,1996;Beitz,2001;Giddens,2004;Stiglitz,2005). Hirst and Thompson (1997) provide the empiric of inequality arising from globalization and interrogate the genuine developmental underpinnings of globalization. They observe that there is increasing inequality arising from capitalist system. These are just a few examples among many that identify complexities and contradictions of globalization (Rosenau, 1996).

On its part, the literature on culture mutation has been scant. Culture mutation in this paper refers to partial or complete excision of prevailing totality of ways of life and attitudes of a people overtime through subtle or obvious rejection or imbibing of alternative ways of life which alters existing attitudes or values (Amadi and Agena 2015).

At the conceptual level, Miege (2011) posits that for over three decades, a group of scholars have developed the "Cultural Industries School". Some of the key figures, main contours, and diffusion of this school, especially in Europe, Latin America, and parts of Canada, are outlined well enough. The goal is to grasp the contemporary mutations affecting the cultural, information, and communications industries. Both Miege, (2011), and Rob,(2014) identified some modes of globalization induced culture mutation, namely;

Mutation 1: the current globalization of, and expansion in, market consumption (of culture and information).

Mutation 2: the increasing dominance of communications industries over content industries,

Mutation 3: the power of ICTs (digital) over cultural and informational practices, Mutation 4: maintenance of content industries but emergence of common inter industry characteristics.

Such capitalist exploitation is reinforced as Hofstede (1980) identifies five core features of national culture encompassing "power distance, individualism versus collectivism, masculinity versus femininity, uncertainty avoidance, and long term versus short term orientation. Power distance is the distribution of power in terms of the way subordinates expect inequality".

Culture sustainability has been a challenge in recent times. The systemic global production debate (Sarmela 1975) argues that the West adopted a mutual technological culture which satisfies international standards informed by the logic of the imperialists' long standing economic motives of resource exploitation. 
Luke A Amadi et al.

Table 1. Super Culture and Local Culture Dynamics

Super Culture

Local Culture

\begin{tabular}{|l|l|}
\hline Technological, differentiated & \multicolumn{1}{|c|}{ Non-technological, natural world order } \\
\hline $\begin{array}{l}\text { Scientific system of knowledge } \\
\text { controlled by elite groups }\end{array}$ & $\begin{array}{l}\text { System of traditional knowledge; controlled by folk } \\
\text { wisdom }\end{array}$ \\
\hline $\begin{array}{l}\text { Efficiency,organization } \\
\text { directed; }\end{array}$ & $\begin{array}{l}\text { Self -Community } \\
\text { directed }\end{array}$ \\
\hline Standardized global Traditional, solutions & locally adapted solutions \\
\hline
\end{tabular}

Source :Sarmela (1975)

The so-called primitive cultures are essentially small community-cultures that gain their ethnic characteristics through adaptation to a specific environment. The individual's relationship with his community is the prime relationship in non-technological communities (Sarmela, 1975).

The literature reviewed suggests that there is for a theoretical valid debate on globalization and culture mutation which is a novel contribution and a missing research agenda. Most critical in these theories is the scant debates concerned with the concept of globalization as an institutional organizing structure of culture mutation. The paper follows the conclusion of Stiglitz (2005:6) that: "rich people benefit from globalization, to the detriment of poor people"-. As a result a rethinking on the current wave of globalization is expedient. Stiglitz (2005) shows how globalization increasingly affects the developing countries.

If we make sense of globalization as historically and institutionally bound to culture, then we shift culture studies from localized examinations of individual behaviors and group practices to critical analyses of wider social frameworks as an organizing institution. By doing so, we denaturalize culture mutation as a taken-for-granted concept; we begin the work of unmasking its dimensions as well as implications and its links to larger historical and material conditions of the poorest societies and more importantly on policy discourse to fill the identified gaps.

\section{Dimensions of Culture Mutation in Africa}

Africa's external interaction such as trade with the outside world including Europe and America dates around the 15th century(Rodney,1972;Kwame,2006). This unequivocally changed the existential realities of Africa in a number of ways economically, socially, culturally, politically etc (Kwame, 2006). As highlighted, culture mutation is a colonial legacy. During colonialism, the central evidence of incipient culture mutation was the European's assumption of superior cultural traits and contradictory colonial legacy - through conquests and the looting of African cultural artifacts which not only distorted African value system but demonstrated the exploitation of Africa. The Industrial Revolution made Western economies stronger as the slave trade was abolished. They increasingly based their inroads to Africa on economic and cultural imperialism including cultural and religious dislodgment through Christianity. Amin (1972) identified three distinct patterns of colonial penetration in African namely; Africa of the colonial trade economy, Africa of the concession owning companies and Africa of the labor reserves.

The decay in African traditional institutions is discernible; the colonial state destroyed oral tradition, the pristine African ways of life and imposed a new mode of behavior. (Amadi and Agena,2015). European languages became official mode of communication along colonial lines "French speaking Africa or French West Africa" "English speaking Africa or British West Africa" there are also Spanish, Portuguese and German East Africa (Ubani,2012).

Venerated African traditional institutions such as the deities, kolanut, rituals, libations, gods, goddess and more recently the marriage institution remains threatened by resurgent Western same sex marriage(SSM) which erodes African marriage ethics (Amadi and Agena,2015). There has been evidence of increasing dearth of cultural practices. Among the Igbo of Eastern Nigeria, Amadi and Agena (2015) demonstrate the dearth of libation and similar cultural rituals such as traditional blessing of kolanut. Kwame (2006) shows how the Ghanian traditional belief system is increasingly diminishing with refrain from cultural values.

The land grab and plantation agriculture eroded African land tenure system and pristine agricultural practices linked to the earth goddess. In its place Western mechanized capitalist farming with organic 
chemicals and fertilizers decimate biologically useful creatures and vitiate soil fertility. In Southern Africa such capitalist proclivities are perceptible.

Christianity was an effective tool of culture dislodgement and reached the continent of Africa in the 1st century spreading to Sudan, Egypt, Ethiopia and Eritrea. Presently it has about 285 million devotees (Ubani, 2012). Muslim reached Africa in the 7th century, with about 285 million Islamic faithful. There are other religious groups of non-Christian and Muslim extraction in Africa (Ubani, 2012; Amadi and Agena, 2015). Beginning in the last decade of the 20th century and the 21st century, the novel relationship which emerged between Africa and the rest of the developed society could be rightly termed globalization.

The KOF Index (2011:2) which stands for a name of a Swiss company: KOF Swiss Economic Institute (Konjunktur-forschungsstelle), conceptualized globalization as "a process that erodes national boundaries, integrates national economies, cultures, technologies and governance and produces complex relations of mutual interdependence". It provides three sub dimensions of globalization: "personal contacts, information flows, and cultural proximity". In the personal contacts dimension, culture dislodgement is discernible as Africans move into Western countries, interact freely and imbibe new modes of attitude including culinary culture, dressing, global connectivity made possible through social media networks etc. The information flows "dimension aims to provide ideas and knowledge including access to information .This accounts for rapid increase in internet use ,television, radios, newspapers, mobile phones, Ipads, social network sites and new media . While the cultural proximity explores the mode of culture contact that results dislodgement of local culture. The information flow measures the spread of ideas, extent news and information exchanges, images, and norms. Likewise, Castells(2000:693) identified dimensions of social change and interaction that results to a new society ,the first being a new technological paradigm, which deploys new technologies, the second dimension is globalization, conceived as the technological, organizational, and institutional capacity of the core components of a given system (Castells,2000:693), the third "is the enclosing of dominant cultural manifestations in an interactive, electronic hypertext", including the internet which has a rapid spread across the world(Castells,2000:693).

Amadi and Agena (2015) argue that the "internet personality" had emerged. In South Africa, Kenya, Nigeria, Ghana, Botswana, the internet personalities who engage in novel online sexuality and dating which is counter to African culture, are emerging and distorting the traditional African lifestyles. There are Western song rappers, addicts and promoters of European Premier Leagues (EPL)to the relegation of African local leagues(Amadi and Agena,2015).The "internet culture" and GSM information flow facilitated the Arab Spring of 2011 though a commemorative dimension. The "GSM revolution" is a variant of culture mutation and capitalist exploitation. The United Nations Conference on Trade and Development (UNCTAD, 2007), contend that mobile phones have become the most widely used form of ICT by African businesses (Helton, 2012). Sullivan (2005:125) observes that "never before has a technological innovation been adopted as quickly as the introduction of cell phones in developing nations". Sullivan (2005:125) argues that "the social and economic impact of this technology is much more dramatic and disruptive in the developing world, where many people have never had phones before, let alone computers or Internet connections-or bank accounts". He contends that the "cell phone has not only bridged the digital divide but is changing the way people who have never had bank accounts or credit cards deal with money" (Sullivan,2005:125). Explicating the situation in Africa, Helton, (2012), reports that there are about 84 million mobiles phones which give primary internet connectivity. See Table 2 .

Table2. Africa: Comparison of Types of Communication Technology in Use.

\begin{tabular}{|l|l|}
\hline 2011 Technology & Subscriptions per 100 Inhabitants \\
\hline Fixed Telephone Lines & 1.4 \\
\hline Broadband & 3.8 \\
\hline Computer in Home & 7.8 \\
\hline Mobile Phone & $53.0^{*}$ \\
\hline
\end{tabular}

Sources: Helton, (2012), International Telecommunication Union (2011),

In their study, Medhi et al., (2009) describe menu interfaces- Globe Telecom G-Cash (Philippines) and Safaricom M-PESA (Kenya) built on similar menu interface. The mobile phone produces classified communication that the user indicates choices using up and down keys. G-Cash is 
accessible in English alone, M-PESA is accessed both in English and Kiswahili. WHIZZIT (South Africa), nonetheless is menu-based, involves a USSD message, short code, entered in a specific syntax, encompassing digits and other symbols in the menu. Winseck (2011) examined the rise in telephone users worldwide from 800 million in 1998 to 4.2 billion in 2009, while this users rose to 4.5 billion subscribers. Winseck (2011:9) recounts that "a total of 2 billion people had access to the internet in 2010, and about 10 times the number in 1998. Today, 28.7 percent of the world's population has internet access, up greatly from 5 percent 12 years ago, He argues that it is still sobering that 70 percent of people have no access whatsoever. In 1996, two-thirds of all internet users lived in the United States; since 2009, China has had the most internet users, although citizens in the United States are more than twice as likely (77 percent) to have internet access than their counterparts in China (30 percent)"

The contradictions of the information age (Castells, 1996), is a springboard of seminal debates. The gap between the "info rich" and the "info poor" is still very significant. In poor African countries, people who subsist on less than $\$ 2$ dollars per day are unlikely to have access to the internet or afford a mobile phone (Amadi,2012). While the capitalist societies" are more than 300 times likely to have broadband internet access and mobile telephones (ITU/UNCTAD, 2007: 22; ITU, 2010: 195; Internet World Stats, 2010; Winseck,2011).

Wade (2002) recounts that information and communication technologies are being oversold as a solution to corporate efficiency and governance response to citizens. Similarly, the world wide web has taken Western culture to the next level to the relegation of periphery cultures such as the Web platforms including, Web 2.0,social software, Rapid share, Wikipedia, MySpace, Facebook, YouTube, Google, Blogger, WordPress, Hi5, Flickr, Photobucket, Orkut, Skyrock, and Twitter are reflective of the internet revolution (Fuchs, 2011). This novel technological mode of interaction alienates the majority of the rural Africans who are illiterates. Helton (2012) identifies digital divide at the wake of modern technological advancement.

The glowing Western internet identity and exploitation is what Appadurai termed a predatory identity (Appadurai, 2006). Using the Iranian experience, Kraidy (2002) shows how poor censorship is spreading Western culture across the periphery societies including publications in popular Western media suggestive of the rise of American popular culture. He demonstrates similar Western cultural influence in Malaysia and India. Hall,(2001) argues on the increasing dynamics of culture change on the Caribbean and Latin America arising from Western cultural influence. This is reinforced by debates which conceive Western culture as influential culture. Dreher(2006) for instance, contends that the Western culture had emerged as the most influential culture worldwide. Such persuasions inform the culture logic of mutation as a result of cultural proximity.

On the lure of the West, the Western consumption hegemony is critical (Wernick, 1997; Davidson and Hatt, et al; 2005; Schor, 2005; Harvey, 2005). This has been driving resurgent global cultural identity including McDonalds, IKEA stores, (Dreher 2006). UAC's Mr Biggs, Starbucks, Coca-Cola and imported used products like clothing and cars are increasingly affecting African patronage of local brands (Amadi and Agena, 2015). Such increasing preference to imported cheap Western clothes had overtaken the home made clothing in Africa.

In Zimbabwe, Muyale-Manenji (1998) shows such increasing preference. In Aba South Eastern Nigeria reputed to be the "Japan of Africa", locally made products are often not patronized as preference for imported fairly used wears remain at issue. Similarly, in Kenya, Muyale- Manenji (1998) reports that the women involved in sisal bags-"kiondos "manufacturing business were discouraged when they realized that same bags were manufactured in Japan and sold cheaper in East Africa and neighboring countries.

Such foreign in-roads had made Africa a dumping ground for finished goods, (MuyaleManenji,1998). Davidson and Hatt, et al; (2005) contend that the growing challenges of consumption of sustainability has critically posed threats to the rest of humanity since the 21 st century as the high income countries engage in a wide range of deleterious patterns of consumption which affects the periphery cultures and the wider human environment such as chemical weapons, atomic bombs and similar explosives. Western cuisine such as spaghetti, macaroni, burger and noodles are household names for Nigerian children (Amadi and Agena, 2015). Western lifestyles dominate the African selfperception, such as dress code, make up etc .The aim is to keep abreast with trends of the changing 
times or "what is in vogue" (Muyale- Manenji,1998). Appadurai (1996) identifies the circulation of Western popular music, such as Jazz, Disco, Pop and similar European and American music, the impact of the film industry, including Bollywood and Nollywood and contends that this is more than a simple instance of Americanization in the United States after all, there are fewer Americans interested in these songs. Kraidy, (2002) demonstrates the spread of Western movies as an article from the Washington Post, reports about an American film Marketing Executive who explains the increasing popularity of American popular culture abroad (Waxman,1998:1, cited in Kraidy,2002). Appadurai (1996) re-echoes that the phenomenon of cultural appropriation is symptomatic of a globalized nostalgia for the present. Castells, (2000) underscores this change as he contends that the multi dimensional changes are taking place in the 21 st century with people's little knowledge of what the change is all about. Uni-culturality or the rise of global culture has been one of the central contradictions of globalization (Rosenau, 1996; Appadurai, 1996; Jameson, 2000; Amadi and Agena, 2015).

The idea is that with globalization in place there is now a global culture. Such Western culture mutation strands have received contrary views and opposition. Smith, (1990) identifies a repertoire of lifestyles, value system, symbols and beliefs which are emerging as modes of behavior. The Western sexuality identity such as the ongoing same sex marriage (SSM) has become associated with Western cultural imperialism as the United States on June 26th,2015 adopted the legalization of same sex marriage which is abhorrent in Africa and most periphery cultures. As the US pushes for its universalization, a number of African countries are opposed to it. For instance, in the 2015 visit of American President Barack Obama to Kenya, his African brothers opposed and resisted any idea to include same sex marriage in his agenda.

National cultures and values change over time, though in a path dependent rather than convergent ways (Inglehart and Baker, 2000). Western Education and mutation of African culture is discernible (Tikly, 2001; Moahi, 2007; Amadi and Agena, 2015). As a vehicle for propagation of Western values and thoughts Western education promotes Western values while African culture is relegated to the background. It was only recently that research on African cultural studies were funded and included in the curriculum of most Western Universities. Kanuka (2008) shows that the emergence of Western models such as e- learning technologies mirrors the concerns and curriculum of Western knowledge system against the periphery. This propagates the dominant culture.

Competition for Western education resulted to the relegation of traditional practices. Kwame (2006) recounts that the colonial initiated education had less value for African knowledge system and distorted African traditional education A critical mutant variant of Western education was the subtle displacement and dissociation of African traditional education and value system such as folklores, African oral history and tradition, myths, belief, farming activity, cooking etc. According to Kwame, (2006) such values through which education and knowledge is transmitted include African folklore, idioms. Others such traditional wrestling among able bodied men such as the Igbo of Eastern Nigeria, native herbal medication and traditional midwifery becomes alienated (Amadi and Agena, 2015).

Language is central to culture preservation as most cultural practices are communicated and handed over from one generation to the other. Kwame (2006) observes correctly that no culture is possible without a language. The decimation of the periphery language negatively impacted global communication of African world view as most interpretations on African culture are oral and poorly told in Western languages. This is an inherent contradiction of culture mutation "hence to kill a language is to kill a culture"(Kwame ,2006).

English language fluency became a yardstick for intelligence to the gradual extinction of African languages (Paa Kwesi, 2005; Kwame, 2006;Amadi and Agena,2015). Western accent and mannerisms become more pronounced among Africans than propagation of African philosophy. This has been a common trend in Nigeria, South Africa, Ghana,Tanzania,Kenya,Uganda etc. Mutation of African myths, taboos and belief system are significant relics of culture loss. In parts of Ghana according to Kwame, (2006) it is a taboo for people to go to the farm on certain days of the week, such practices which are at variance with Western culture are gradually fading away. In Eastern Nigeria, similar norms are observed on a day called Ekeh market day venerated and kept sacred and abhorrent to engage in farm work (Amadi and Agena, 2015). Similarly, the elitist online marketing such as network marketing and the alienation of African rural market woman are important strands of culture 
mutation. Women constitute about $60 \%$ of the communal farmers in Zimbabwe, most of them are illiterates involved in rural marketing (Muyale-Manenji, 1998).

The dearth of African mores and values are increasingly affecting the morals and ethos of African children. Ethos imply peoples' self-understanding as well as self- presentation in the wider society through their thought and practice (Ubani, 2012). Pinging, BBM, Facebook, Instagram, chatting, online sexual intercourse, pornography culture, etc, expose children to un-African ways of life (Amadi and Agena, 2015).Cultural norms involving children sitting and sharing folklores and didactic tales in the evenings which inculcate ethics and values, respect, morality, myth, love, unity, peace into the child is giving way(Muyale- Manenji, 1998). On the contrary, Children from affluent homes are engaged in playing video games, watch television and foreign movies, enrolled in international schools that offer English and other "international" languages that do not propagate or reflect indigenous African values(Muyale-Manenji, 1998). Songs and dances have been increasingly Westernized with beats such as Michael Jackson and others (Muyale- Manenji, 1998).

Contrary scholarship posits that despite the growing literature and concern on the disappearance of the periphery cultures, some cultural values are still in practice( Inglehart and Baker ,2000).Others contend that some of the myths require transformation to meet realities of the changing times (Baffoe, 2005; Kwame, 2006). Muyale-Manenji, (1998) reinforces the inherent transformation in a culture and contends that despite societal change, culture continues to give a community a sense of identity, dignity, continuity, security and binds society together. While the confrontationist scholarship such as Kenyan social commentator, Mwiti Mugamba contends that the future of Africa can only be forged from accepting and minding the socio-cultural present. That the colonial "hangovers", have come to stay (cited in Ubani, 2012). Cultural globalization can create changes in the perceptions and attitudes toward a whole social life and people's existence. The effect of this depiction of existential reality is that cultural ethos and practices are eroded as globalization gradually distorts these norms which are taken for granted and unquestioned.

Culture restitution and confrontation of globalization are strategies propagated in this article. Culture reinstitution is a programme of compensation and retrieval of "plundered African cultural artefacts" by the West - from the holocaust of slavery, slave trade, colonialism, neo colonialism and imperialism. This takes the form of recreating African cultural values at all levels of the society. It maintains that such reinstitution should be a strand of culture sustainability to build and strengthen the culture capacity of the periphery societies where pro-culture policies could be formulated and implemented. Equally, to meet with the demands of the changing times, indigenous culture sieve an approach for collective consensus and cultural reinvention is important. It aims to identify cultural traits that should be strengthened, discarded or practiced as a way of life and value system of the people by the people, such as widowhood practices, female genital mutilation, culture logic of gender inequality and marginalization of women etc, require novel awareness and transformation.

Confrontation is a strategy which aims to oppose Western globalization as anti- culture. Rather than delinking, a strategic overhaul of the content of cultural globalization is suggested. The aim is to resist the onslaught on African culture and identity. And to further redress the Western globalization imaginary circulating in contemporary periphery culture. Also to understand the ways in which globalization is historically fabricated in the distribution of economic resources, cultural power, and social control across Africa. Culture is not imposed from without- such as the ongoing Western same sex marriage, etc.

\section{Conclusion}

The present literature argues that without institutionalized equitable frameworks -that is, the ideological and organizational regulation of relations, globalization may not be resourceful among poorer societies. The article has attempted to present arguments on how Western globalization is increasingly dislodging African culture through technological advancement, distortion of cultural identities such as food systems, names, attitudes, including virtual online sexuality, emerging "internet personality" etc. There is resurgence of Western lifestyles and modes of behavior such as the clamor for same sex marriage, Western consumption patterns, Western identity, dress codes, music, films and similar alien inclinations etc. Such hugely significant changes explored within culture mutation contexts implicitly point to the fact that periphery culture sustainability is a missing component of Western globalization. 
While the article argues against globalization as an instrument of culture mutation, it has also demonstrated that culture mutation is not inherently bad in itself, except that it erodes certain African pristine values and identities that are deemed necessary to be preserved. The debate is subject to further research as it is a well-known fact that there is now a mix of cultures, genetically mutilated foods, crops and animals, creolization, acculturation and adaptation - which is not unidirectional as it is made out to be. It is rather a reciprocal flow, albeit poor countries are most impacted.

The article recounts that there is limited empirical validation which is a limitation, beyond this, rather than merely state the obvious that globalization induces culture change, the article demonstrated dimensions of culture mutation and advanced strategies to fill the identified gaps namely; restitution and confrontation.

The presupposition of our contention is not a static social formation rather to evolve a home grown internalized norm to confront what Castells (2000) called "a new society". Nothing is wrong with a new society but everything is wrong with a distorted cultural heritage arising from so called new society as we have discussed.

What the debates advanced here have done is to add plasticity to what has been ongoing. The picture painted so far is a picture of culture dislodgement in a fierce and persistently unequal capitalist order. The arguments made in the present research are not new. It has been part of historical debates on identity and culture. Globalization has confronted culture one of the core social institutions of Africa head on. Asserting that it is neither natural nor inevitable instead a contrived and taken-for- granted situation, especially among the poor vulnerable societies is not out of place. A return to cultural values or possible juxtaposition of both is suggested (Amadi and Agena, 2015). This includes the preservation of the African identity-morals, lore, ethics, mores, values, norms - The ways of life of the people encompassing all those social, material and non -material practices in which peoples' identity is at stake.

Attending to these practices requires an internal critique of globalization and provision of alternative mode of behavior and understanding of cultural norms and ethics. In the interest of cultural preservation, sustainable and equitable development, there is need for an inclusion of culture as a component of sustainable development, like environmental, social and economic components. Sustainable development cannot be attained in an era of cultural imperialism and exploitation. Beyond that, is a re-examination of the ways in which development theories of globalization contribute to the cultural development and transformation of the poor-societies. Cultural theories of development should now look at how the values and norms of the periphery societies could positively reshape economic, social and political development rather than treated as naive and uncritical past depictions.

\section{REFERENCES}

Amadi L ,Agena J (2015).Globalization ,Culture Mutation and New identity :Implications for the Igbo Cultural Heritage. African Journal of History and Culture vol.7pp16-27.

Amadi L ,(2012).Africa :Beyond the "New" Dependency: A Political Economy. African Journal of Political Science and International Relations, Vol. 6 (8), pp. 191 -203.

Amin S (1972)Underdevelopment and Dependence in black Africa-origins and contemporary forms the journal of modern African Studies,10.4,pp.503-24

Amin S. (1997). Capitalism in the Age of Globalization .London, Zed.

Appadurai, A.(1996). Modernity at Large: Cultural Dimensions of Globalization. Minneapolis, University of Minnesota Press.

Appadurai, A(2006). Fear of Small Numbers. Durham, NC: Duke University Press

Baffoe M (2005)."These obsolete customs and traditions must be scrapped"!! Available at www.ghanaweb.com. Accessed,10/6/2015.

Beitz, C. (2001). “Does Global Inequality Matter?” in Thomas W. Pogge, ed., Global Justice Oxford

Carnoy, M. (2000). Sustainability, Work, Family, and Community in the Information Age. mCambridge, MA: Harvard University Press

Castells, M.( 1996). The Rise of the Network Society Oxford, Balckwell.

Castells, M (2000a). The Information Age: Economy:, Society, and Culture. 3 vols. 2d Ed. Oxford \& Maiden, MA: Blackwell. 
Collier, P (2007). The bottom billion: Why the poorest countries are failing. NY: Oxford Univ. Press

Crane, D.(2002)"Culture and globalization: Theoretical Models and Emerging Trends"in: Diana Crane,Nobuko Kawashima, Kenichi Kawashima (eds),Global Culture; Media, Arts, policy and

Globalization, London Routledge ,pp.1-28

Davidson D, Hatt K, etal.,(2005) .Consuming Sustainability Critical Social Analysis of Ecological Change.Canada: Fernwood Publishing

Dreher, A (2006). Does Globalization Affect Growth? Evidence from a new Index of Globalization, Applied Economics 38, 10: 1091-1110.

Dorin S.(2006).Culture, Globalisation and Communication: Contemporary Theoretical

Perspectives.Availablehttp://www.observatoireomic.org/pdf/Dorin_culture_globalisation_communic tion.pdf. Accessed on 8/4/2015

Dos Santos T (1970). The Structure of Dependence The American Economic Review,Vol.60,No.2PP21-236

Ekeh P(1975). Colonialism and the Two Publics in Africa: A Theoretical Statement Comparative Studies in Society and History, Vol. 17, No. 1., pp. 91-112

Ferguson J (2006). Decomposing Modernity: History and Hierarchy after Development. Department of Anthropology University of California, Irvine

Frank G (1968). Capitalism and Underdevelopment in Latin America New York: Monthly Review Press.

Fuchs C (2011).The Contemporary World Wide Web Social medium or new space of accumulation? In: Winseck D and Jin D(eds;). The Political Economies of Media The Transformation of the Global Media Industries .Bloomsbury Publishing Plc 36 Soho Square, London W1D 3QY, UK

Giddens, A. (1999)Runaway World: How Globalization is Reshaping our Lives,London: Profile.

Guillen, M. (2001).“Is Globalization Civilizing, Destructive or Feeble? A Critique of Five Key Debates in the Social Science Literature", Annual Review of Sociology 27.

Grauman. C, (1999). Soziale Identitanten, Manifestation sozialer Differenzierung und Identifikation. In: Viehoff,R,Segers R.T (H.g):kultur,identitat,Europa,Frankfurt/M.,S59-74 In;Hauser R Culture Identity in a Globalised World?A Theoretical Approach Towards the concept of Cultural identity. Institut fur Technikfolgenabschazung und Systemanalyse(ITAS)

Hall. S, (2001).Cultural Identity and Diaspora" the Journal Framework (no.36). Available at www. unipa.it/ michele. cometa/ hall_cultural_identity.Accessed 8/7/2015

Hall S, Held D , Hubert D, Thompson K, eds, (1999) Modernity and Its Futures. London: Polity Press / The Open University, 274-295

Harvey, D. (2005). A Brief History of Neoliberalism. Oxford: Oxford University Press.

Helton D (2012). Bridging the Digital Divide in Developing Nations through Mobile phone Transaction System. Business Quest. Available at: www.westga.edu/ bquest/2 012/divide2012. accessed 10/5/2015

Huntington S, (1997).The Clash of Civilizations And the Remaking of World Order. The Reader May/June.

Hofstede, G. (1980). Culture's Consequences. London: Sage.

Inglehart R, Baker W.(2000). Modernization, cultural change, and the persistence of traditional values. Am. Sociol. Rev. 65.

International Monetary Fund, (2000), Globalization: Threat or Opportunity?, Washington

International Telecommunication Union (2011). Key ICT Indicators for Developed and Developing Countries and the World (Totals and Penetration Rates), available at: http://www.itu.int/ITUD/ict/statistics/at_glance/KeyTelecom.html.

Internet world Statistics - Annual Global Internet Report 2010 available at www.internetsociety.org/ Statistics.(Accessed 9/7/2015)

Jameson, F. (1998).Globalization as a philosophical issue In: F. Jameson, M. Miyoshi (Eds.), The Cultures of Globalization (pp. 54-77). London: Duke University Press 
Kanuka, H (2008). Understanding e-learning technologies-in-practice through philosophies-inpractice. In: T. Anderson \& F. Elloumi (Eds.), Theory and Practice of Online Learning (pp. 91118). Retreived July 29, 2015, from http://www.aupress.ca/books/120146/ebook/04_Anderson_ 2008_Kanuka-Online_Learning.pdf

Kwame, Y (2006).The Impact of Globalization on African Culture. University of Southern Denmark, Odense

Kraidy M, (2002). Hybridity in Cultural Globalization. Communication Theory, 12 (3), 316-339.

Levitt, T (1983). "The Globalization of Markets," Harvard Business Review, 61 (3), 92-102.

Medhi, I, Nagasena Gautama, and Kentaro Toyama (2009). "A Comparison of Mobile MoneyTransfer UIs for Non-Literate and Semi-Literate Users," Conference on Human Factors in Computing Systems (CHI 2009), Boston, MA, 4-9 Apr. 2009, 1741-1750.

Meyer J, Hannan M. (1979). National development in a changing world system: an overview. In National Development and the World System: Educational, Economic and Political Change, 1950-1970, ed. Chicago Univ. Press.

Miège B, (2011)"Principal Ongoing Mutations of Cultural and Informational Industries" In: Dwayne Roy Winseck and Dal Yon Jin (eds;) .The Political Economies of Media: The Transformation of the Global Media Industry. Blumbury Academic, London

Moahi, K. (2007). Globalization, knowledge economy and the implication for Indigenous knowledge. International Review of Information Ethics, pp7, 1-8

Moahi, K. (2007). Globalization, Knowledge economy and the implication for Indigenous knowledge. International Review of Information Ethics, 7, 1-8.

Muyale-Manenji F (1998). "The Effects of Globalization on Culture in the eyes of an African Woman"; Echoes' Bulletin. World Council of Churches, Geneva, Switzerland Available at :http://www.wcc coe.org/wcc/what/jpc/effglob.html Accessed 5/8/2015

Ohmae K (1995).The End of the Nation State .New York :Free Press.

Onwubiko,K (1967).School Certificate History of West Africa :Ad 1000-1800.Africana Feb Publishers Limited.

Paa Kwesi I (2005). "The colonial environment and African languages" The Language Dialog. Feature article available at http://www.ghanaweb.com/GhanaHomePage/NewsArchive/TheLanguage-Dialog-77114.Accessed 7/7/2015

Pedersen. T, (2008). When Culture Becomes Politics: European Identity in Perspective, ,Aarhus University Press. Rodney, W. 1972.How Europe Underdeveloped Africa. Washington DC. Howard University Press.

Rosemond J(1999).Family Building: The Five Fundamentals of Effective Parenting. Akansas: Andrews McMeel Publishing.

Rossenau ,J (1996). Complexities and Contradictions of Globalization. World Politics. Cambridge: Cambridge University Press

Rugman, A (2000) .The End of Globalization. Random House. London. Amacom-McGraw Hill: New York.

Ruigrok W, van Tulder R(1995) .The Logic of International. Restructuring. London: Routledge. XVI, $344 \mathrm{pp}$

Said E (1993). Culture and Imperialism Vintage Books, New York

Sklair, L (1991). Sociology of the global system. New York: Harvester Wheatsheaf

Sullivan, N (2007). You Can Hear Me Now: How Microloans And Cell Phones Are Connecting The World, San Francisco, CA: John Wiley \& Sons.

Smith A (1990) .Towards a global culture? Theory, Cult. Soc.7.

Smith M, (2002). 'Globalization' the encyclopedia of informal education. Retrieved March 27, 2015 from http://www.infed.org/biblio/globalization_and_education.html

Smith C,Ward, G. (2000). Indigenous Cultures in an Interconnected World, Vancouver: UBC Press

Schor, J.(2005).Prices and quantities: Unsustainable consumption and the global economy, Ecological Economics 55 .309- 320 
Sarmela M, (1975). What is Cultural Imperialism? In : Carola Sandbacka (ed.), Cultural Imperialism and Cultural Identity, 13-36. Transactions of the Finnish Anthropological Society

Tikly, L. (2001). Globalisation and Education in the Postcolonial World: towards a conceptual framework. Comparative Education Volume 37 No.2 pp. 151-171

Trade and Development Report, (2007) Report by the secretariat of the United Nations Conference on Trade and Development. United Nations. New York and Geneva, 2007.Available at www.unctad.org/en/docs/tdr2007_en.pdf (Accessed 5/6/2015).

The NQF: (2011).a democratic project trapped in a neo-liberal paradigm? Journal of Education and Work, 16 (3), 305-323.

Tomlinson. J. (2003). Globalization and cultural identity. Retrieved April 11, 2015, from http://www.polity.co.uk/global/pdf/GTReader2eTomlinson.pdf

Ubani L(2012).Hospitality \& tourism Human Relations Management in Africa. Author House,USA .

UNDP Human Development Report (1999) New York:Oxford University Press.

Waxman M (1998) . A Legal Framework for Systemic Bank Restructuring (June 1998). Available at SSRN: http://ssrn.com/abstract=172984 or http://dx.doi.org/10.2139/ssrn.172984 Accessed 9/7/2015)

Wernick, I, (1997). Consuming materials: the American way.In: Stern, Paul, et al., (Eds.), Environmentally Significant Consumption. National Academy Press, Washington, DC,pp. 2939.

Winseck D.(2011). " The Political Economies of Media and the Transformation of the Global Media Industries" In :Winseck D and Jin D (eds;). The Political Economies of Media:The Transformation of the Global Media Industries .Bloomsbury Publishing Plc36 Soho Square, London W1D 3QY, UK

Winseck D, Jin D (2011). The Political Economies of Media: The Transformation of the Global Media Industries .Bloomsbury Publishing Plc 36 Soho Square, London W1D 3QY, UK

Wikipedia.(2015).Globalization. Retrieved April 14, 2015, from http://en.wikipedia.org/wiki/ Globalization 